\title{
他科 $\mathrm{X}$ 線フィルムに見られた 骨・関節 $の$ 加 令 変 化 (第 2 報)
}

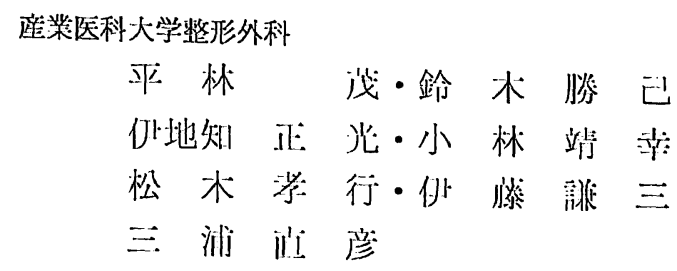

東京人学整形外科

松下隆

\section{Osteoarthrotic changes with aging as seen on $\mathrm{X}$-ray films of other departments.}

(the second report)

by

\author{
S. Hirabayashi*, K. Suzuki, M. Ijichi, Y. Kobayashi, \\ T. Matsuki, K. Itō, N. Miura and T. Matsushita*** \\ *Department of Orthopaedic Surgery, University of Occupational and \\ Environmental Health, School of medicine, Kitakyushu, Japan. \\ **Department of Orthopaedic Surgery, \\ University of Tokyo, Tokyo, Japan.
}

Some roentogenographic changes with aging are observed in the acromioclavicular, sacroiliac, hip joint and lumbar spine. The total number is 1274 . In the third decade, bony spur formation is found in the sacroiliac joint. With aning, bony spur formation appears also in the region of the hip joint and lumbar spine. In addition, after the fifth decade subchondral sclerosis and disc narrowing become visible. Changes of the lumbar spine, especially at the level of $L-4$ and $L-5$, become more remarkable between the fourth and the fifth decade. Osteoporosis is frequently observed in female between the sixth and seventh decade. In the acromioclavicular joint, the changes are not so remarkable as in others, but more remarkable between the sixth and seventh decade. Bony spur formation is due both to the weitht bearing (static element) and to the joint motion (dynamic element), and the main element is thought to be the traction of the joint capsule.

\section{はじめに}

現実の高令化社会の中で, 生体の骨・関節が加令と とあに，いつ頃からどのように変化していくかを知る ことは興味深く, 又, 実際の䛦療に際しX線写真を見 て，それが正常か否かを判断するうえにあ大切なとと であろう。しかし，てれに関して広籁に field work を行うことは現実的に困難である.
一般に，骨・関節のX線写真を㩔る機会は我々监形 外科医が一番多いあのの，㹃際の外来祄療等で見られ るフィルムは，炎症，骨折等により修飾されている可 能性が大きいため，X線写真による生理的な加令変化 の検索には，偶然に振られた骨・関節像が 必要とな

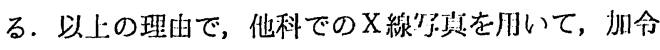
変化を検討したので，沙下の文䣓的考察を含めて第 2 報として報告する。 


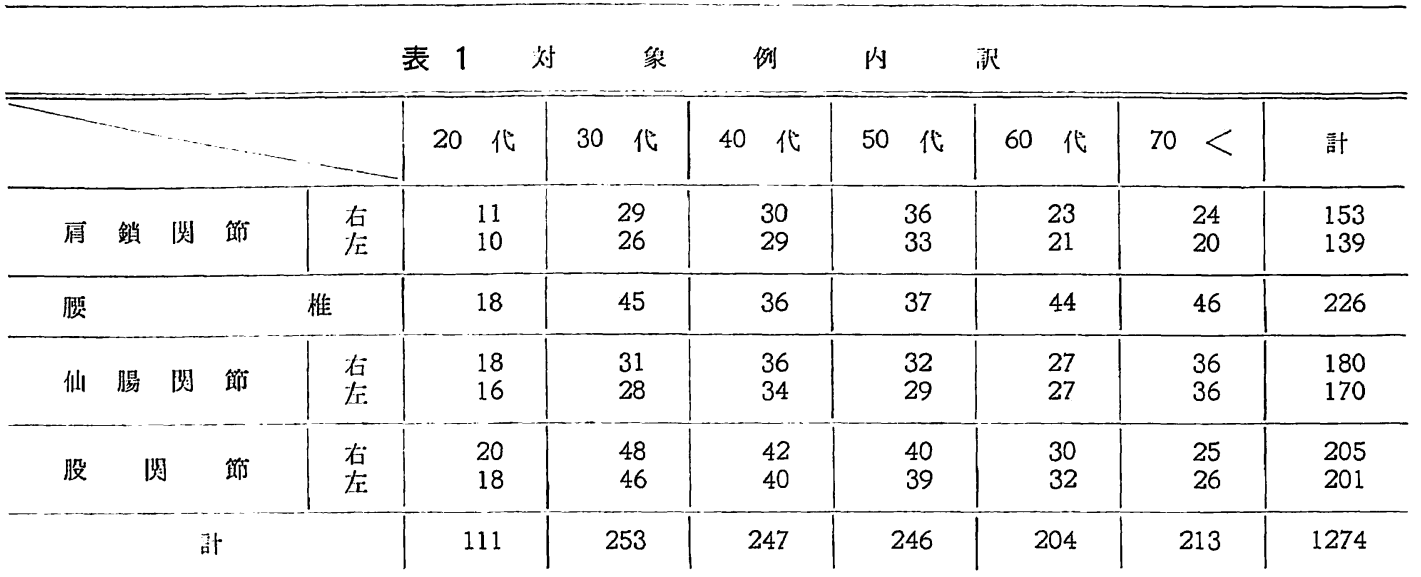

\section{対象および方法}

整形外科領域以外の愁訴で当大学病院を受診し，消 化器, 泌永器系の造影等のX線検査を受けた症例の骨 - 関節像を，1例につき 当科医師二人以上で読影し た. 次に，骨・関節の代表的な加令変化之考えられる (1) osteoporosis, (2) 裂陪・椎間間隙狄小化, (3) 㳄 骨下骨便化，(4)骨棘形成の 4 項目について，所見な し：0点, 所見あり：1点, 著明な所見あり：2点の 点数評洒を行い, 得点の平均值を変化指数として, 年 令別，関節別，項目別に各々検討を行った.

対象関節は，比校的多くフィルムを入手できた肩鎖 阅節，腰椎，仙腸阅節，股関節に限ったが，例数は各 々 292 例， 226 例， 350 例，406 例の合部 1274 例であ る. 性別は男性 235 名，女性 219 名で，又，対象関節 の年令分布は表 1 のごとくである.

\section{結果と考察}

まず年令別の変化を見る之，20 代では仙腸関節 の 畕整形成以外の变化はあまり目立たない（図 1).

30 代に入ると，仙腸関節の骨枣形成はさらに增加

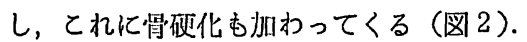

30 代より 40 代にかけては, 腰椎での変化が大きく，

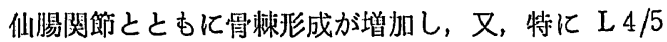
においての椎間間隙狄小化が急增する，肩銧関節，股 関節での骨便化も多くなる（図 3 ）.

50 代では，腰椎での変化がいっそう顕著になり， 骨料形成，椎間間隙狭小化と之も亿， osteoporosis が增加してくる(図4).

この osteoporosisは，概椎を例にとって見ると， 特に女性において 50 代から 60 代にかけての変化が大
20 キ代の変化

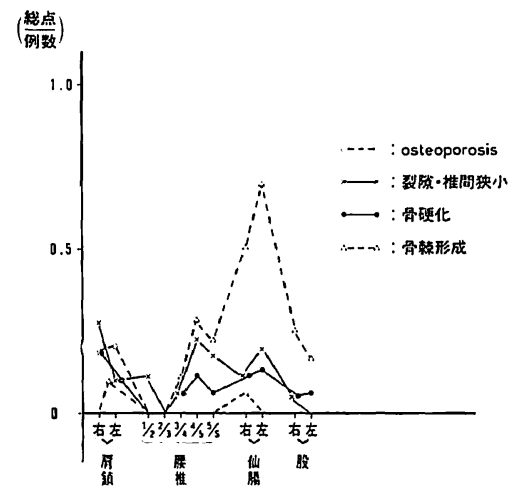

図 1

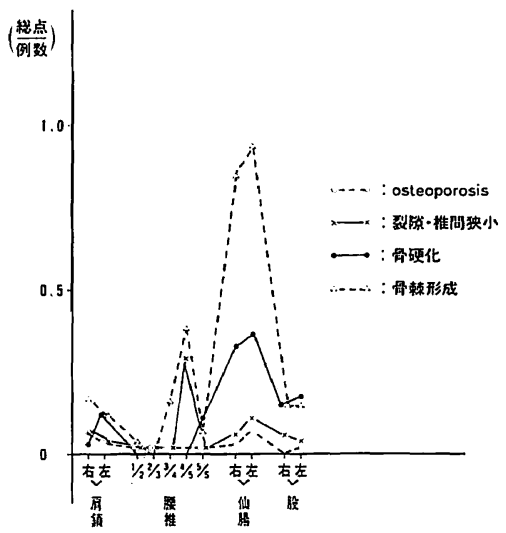

図 2 
40 才代の变化

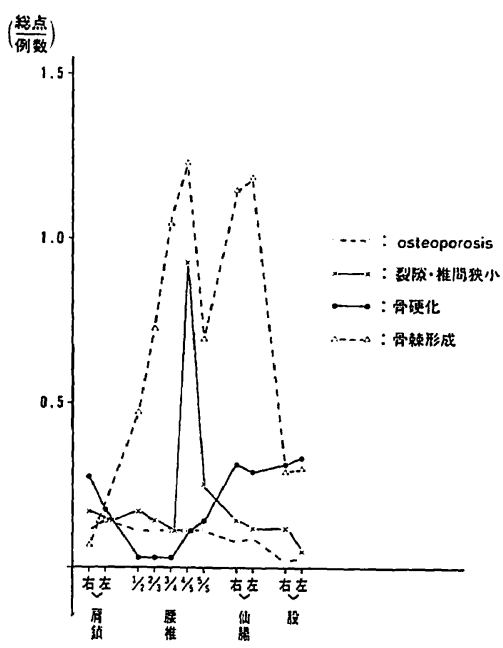

図 3

$50 才$ 代の恋化

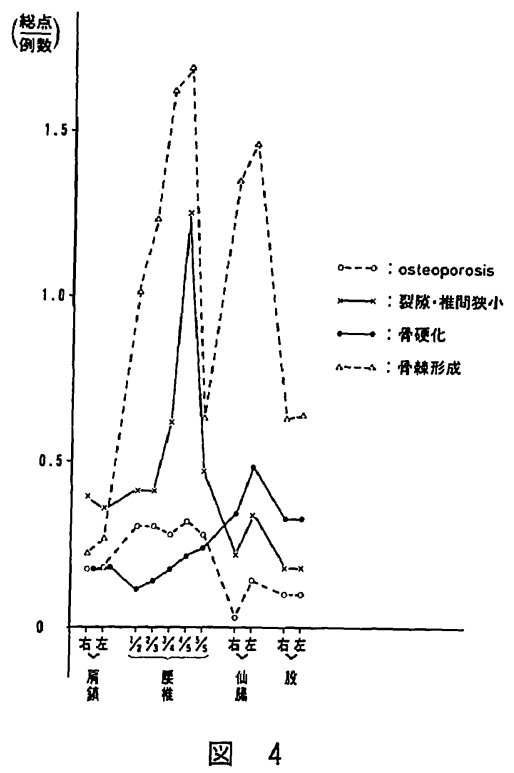

きい(図 5). 男性では, 30 代より加令とともに渐増し ていくのに対し，女性では，40 代からとやや遅れて始 まるむのの，50 代から 60 代に加けて急増し，結局 60 代以上では男性より高値を示している，他の関節む， ほぼ同様であった. postmenopausal osteoporosis を示唆する所見といえる。
腰椎Osteoporosis

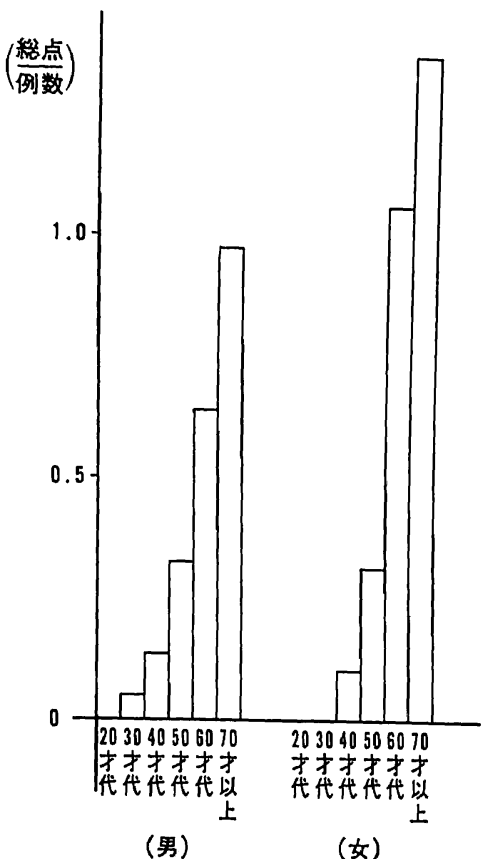

(男)

図 5

右 股 関 節

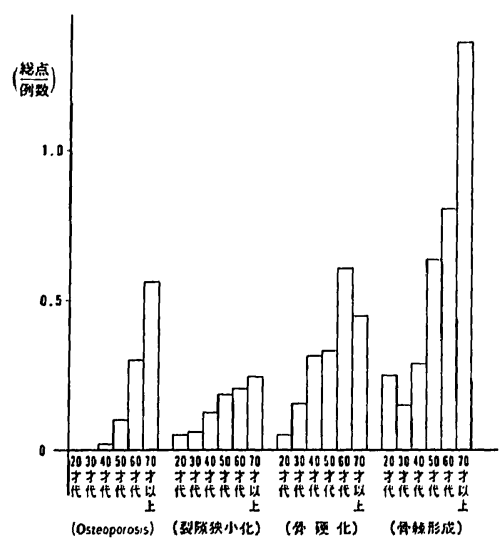

図 6

次に，右股関節と左局銧関節を例にとり，荷重関䬣 と非荷重関節の比較を行うと，まず股関節では，4 項 目のうちの骨棘形成が目立ち，特に70 代以上では著 明である. 裂隙狭小化は，加令による影響があまり見 られない（図6). 
左肩 鎖 関 節

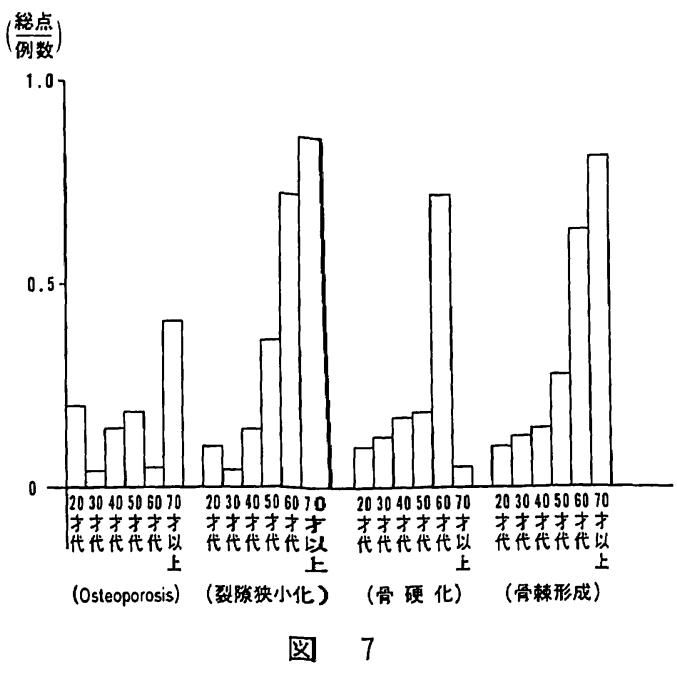

逆に，局銷関節では，裂除狄小化が他の項目に比べ て目立ち，50代加ら 60 代にかけての变化が大きい (図 7)。その理的の一つとして，肩鎖関節では関節 包がゆるく， disc が両肷骬面に対峙して存在してお り，ての disc が加令変化をより受けやすいととが考 えられる。

一方，筲料形成に関して検討を行うと，X線写真で 思られる督刺は，有銷関節では銷骨侧上縁，股関節で は日监辺䋹等に存任する．乙の股関節の骨揀形成は Bombelli によれば，関節创が伸展されその内面にあ

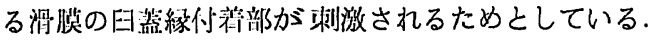
この伸展作用は，荷重により增狆し，関節通動により さらに增加すると考えら 㧈る，一方，肩銷関節は動き の大きい glenohumeral joint の近くに存在し， Kessel によれば，関節通政により主に回旋力を大き く受ける. この反復される回旋力が関節包を伸展さ せ，荷重による影響は股関節より小さいものの骨梀形 成を促すととになると考えられる，以上のように骨欶 形成は，股関節，仙晹関節，腰椎等の荷重関節に顕薯 に見られ，菏重による影響は大きいと考えられる。し かし，非荷重開飾である局銷関節にも少なくはなく， 乙の関節の解剖学的位是是を考えあわせると，骨棘形成 には，荷重という static な要䋕以外に，関節運動と いう dynamic な要紧も加わっておりその主成因は関 節包伸展であると思犼る。
又, 我々の今[间のX線索による検索では骨棘形成 が歌故卜剀硬化等の他の変化に先行して見られたが， 二ノ宮らの家㤙による实験でも骨料形成が軟骨の变性 に少行して発生しており, 同様な結果を得ている.

垠後に，生体の老化という問題を考えるうえで，加 令による骨・関節のX線上での変化はその一表現でし かない反面, 又, いろいろな示唆を与えると思われる. 一方，乙れらの变化は，整形外科的には大きく変形性 関節症の一部としてとらえることもでき，その成因に は，ホルモン・栄養等の生体の生理的変化，労働等 ADL 上の活動状態，荷重関節加否加の棈造力学的問 題等多くの因子が関与していると考えられる.乙れら の相互関係について，今後さらに検討を加えたい．

$$
\text { ま と め }
$$

(1) 20 代より，まず仙腸関節に骨梀形成が 見られ る.

(2) 加令之とむに，骨棘形成は股関節，腰椎等の荷 重関節へと広がる，40 代以上ではこれに軟骨下筲硬 化，裂隙・椎間間隙狄小化が加わる.

(3) 㴗椎では，特に L4/5において，30 代より 40 代にかけての変化が著明である.

(4) osteoporosis は，特に女性において，50 代よ り 60 代にかけて急增し, postmenopausal osteoporosis が示唆される.

(5) 肩鎖関節は，他の関節に比べれば変化は小さい が，骨棘形成を含め，50 代より 60 代にかけての変化 が大きい。

(6) 骨栜形成には，荷重という static な要素之， 関節運動という dynamic な要素が加わっており，そ の主成因は関節包伸展であろう。

$$
\text { 文献 }
$$

1) Bombelli, R.: Osteoarthritis of the hip: Pathogenesis and consequent therapy. Springer-Verlag, Berlin, Heidelberg, New York, 1976.

2) Kessel, L.: Clinical disorders of the shoulder. Churchill Livingstone, 1982.

3）二八宫節夫ほ加：疫形性阅節症の進展——組織 学的㧍よび力学们考察——臨整外. 14: 10— 16, 1979.

4) 山本真ほ加編：变形性関節症のすべて。医歯薬 江版, 東京, 1982. 